Prepared in cooperation with the Louisiana Department of Transportation and Development

\title{
Water Resources of Orleans Parish, Louisiana
}

\section{Introduction}

Information concerning the availability, use, and quality of water in Orleans Parish, Louisiana (fig. 1), is critical for proper water-supply management. The purpose of this fact sheet is to present information that can be used by water managers, parish residents, and others for stewardship of this vital resource. Information on the availability, past and current use, use trends, and water quality from groundwater and surface-water sources in the parish is presented. Previously published reports (see References Cited section) and data stored in the U.S. Geological Survey's National Water Information System (http://waterdata. usgs.gov/nwis) are the primary sources of the information presented here.
In 2010, about 615 million gallons per day (Mgal/d) of water were withdrawn in Orleans Parish, including about $602 \mathrm{Mgal} / \mathrm{d}$ from surface-water sources and about $13.0 \mathrm{Mgal} / \mathrm{d}$ from groundwater sources ${ }^{1}$ (table 1). Power generation accounted for about 75 percent $(464 \mathrm{Mgal} / \mathrm{d})$ of the total water withdrawn. Other categories of use in 2010 included public supply, industrial, rural domestic, livestock, and general irrigation (table 2).

Water-use data collected at 5-year intervals from 1960 to 2010 (fig. 2) indicated that water withdrawals peaked in 1985 at nearly $1,050 \mathrm{Mgal} / \mathrm{d}$.

${ }^{1}$ Tabulation of numbers across text and tables may result in different totals because of rounding; nonrounded numbers are used for calculation of totals.

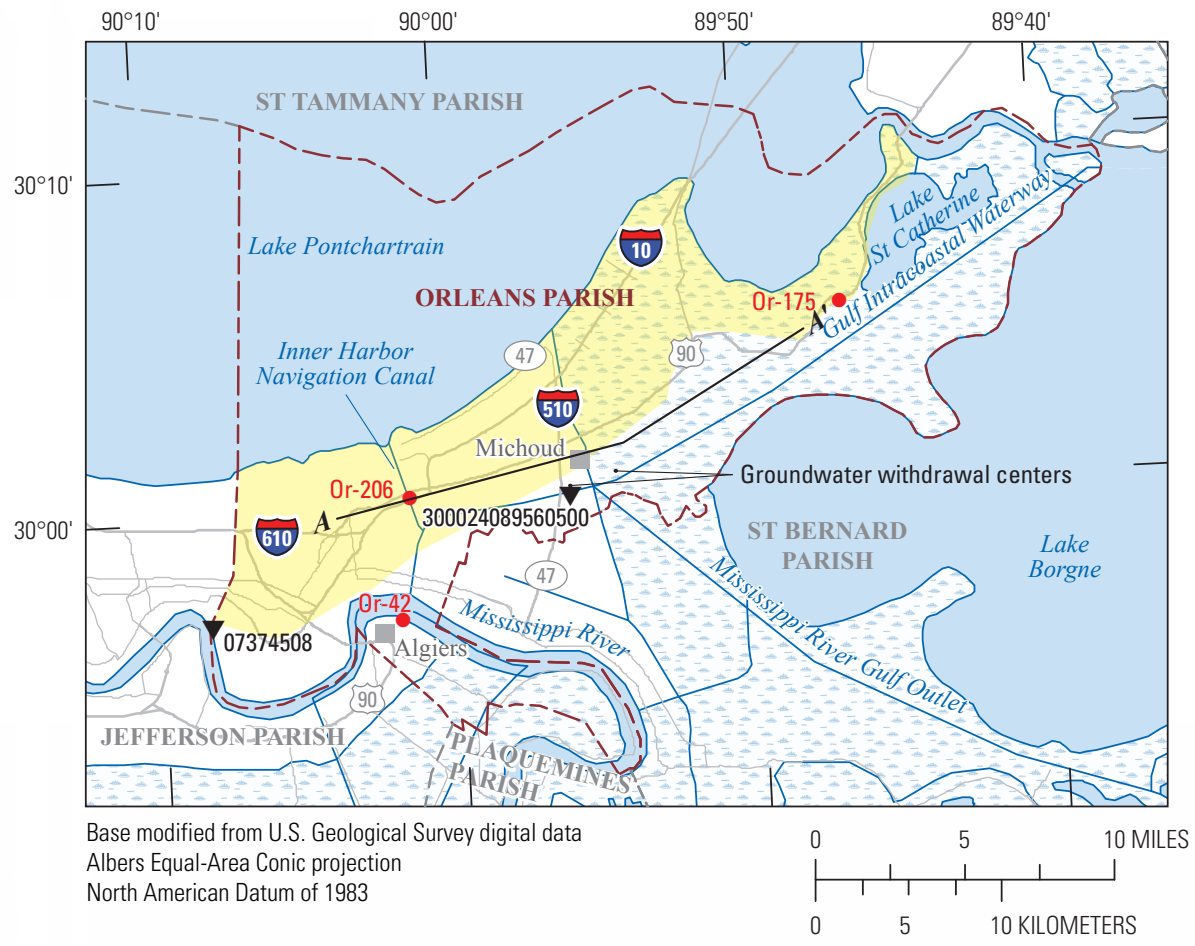

Albers Equal-Area Conic projection
North American Datum of 1983

O 510 KILOMETERS

\section{EXPLANATION}

Approximate freshwater extent of the Gonzales-New Orleans aquifer in Orleans Parish (modified from Prakken, 2009)

Marsh and swamp

$A-A^{\prime}$ Line of section (see fig. 3)

$\bullet \quad$ Well for which hydrograph is shown (see fig. 4)

07374508

Surface-water quality site and number (see table 4)

07373291 Surface-water discharge site and number

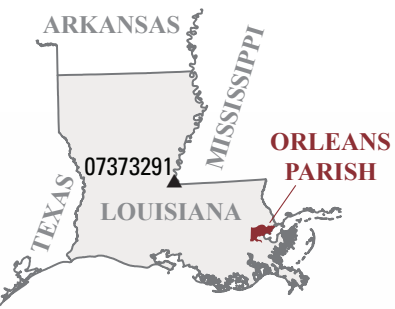

Figure 1. Location of study area, Orleans Parish, Louisiana. 
Table 1. Water withdrawals, in million gallons per day, by source in Orleans Parish, Louisiana, 2010 (modified from Sargent, 2011).

\begin{tabular}{lcr}
\hline \multicolumn{1}{c}{$\begin{array}{c}\text { Aquifer or } \\
\text { surface-water body }\end{array}$} & Groundwater & Surface water \\
\hline Gramercy aquifer & 0.02 & \\
Gonzales-New Orleans aquifer & 12.93 & \\
Gulf Intracoastal Waterway & & 453.20 \\
Mississippi River & & 149.14 \\
Other water bodies & & 0.02 \\
Total & 12.95 & 602.37 \\
\hline & & \\
& &
\end{tabular}

Table 2. Water withdrawals, in million gallons per day, by use category in Orleans Parish, Louisiana, 2010 (modified from Sargent, 2011).

\begin{tabular}{lccr}
\hline \multicolumn{1}{c}{ Use category } & Groundwater & Surface water & Total \\
\hline Public supply & 0.00 & 149.14 & 149.14 \\
Industrial & 1.88 & 0.00 & 1.88 \\
Power generation & 10.87 & 453.20 & 464.07 \\
Rural domestic & 0.17 & 0.00 & 0.17 \\
Livestock & 0.00 & 0.02 & 0.03 \\
General irrigation & 0.02 & 0.00 & 0.02 \\
\cline { 2 - 4 } Total & 12.95 & 602.37 & 615.31 \\
\hline & & &
\end{tabular}

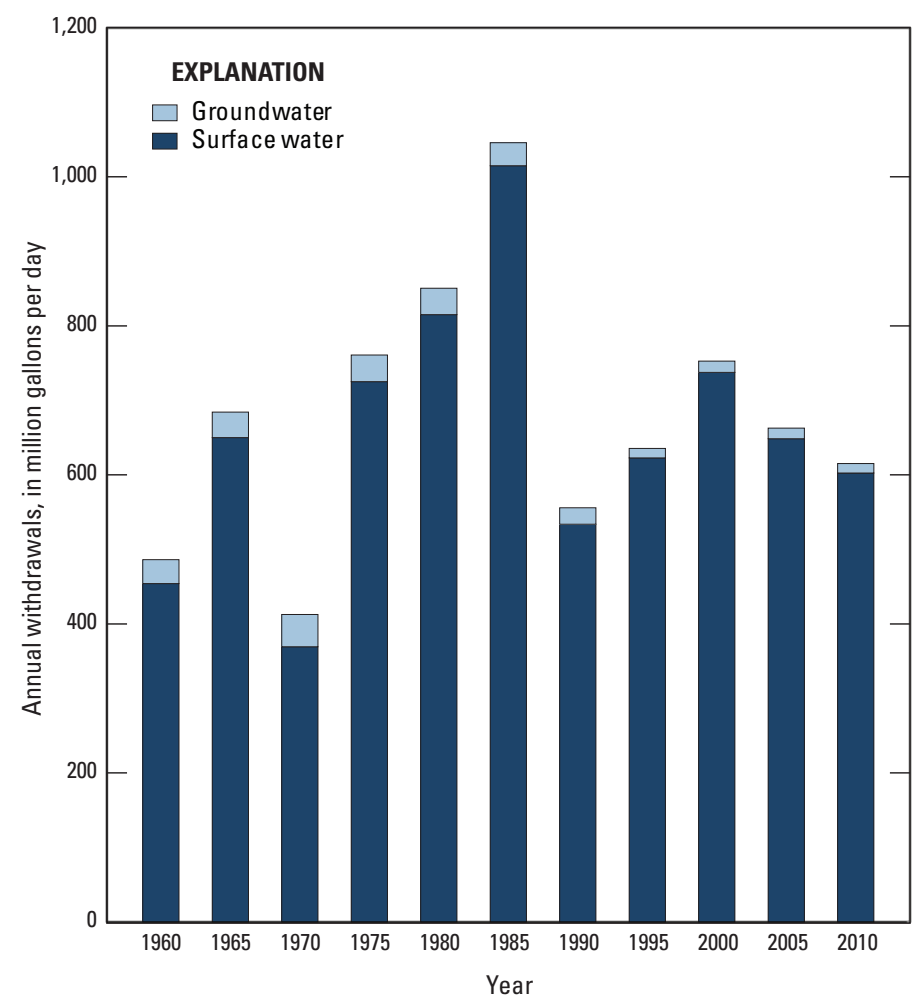

Figure 2. Water withdrawals in Orleans Parish, Louisiana, 1960-2010 (Sargent, 2011).

\section{Groundwater Resources}

The primary fresh groundwater resource underlying Orleans Parish is the Gonzales-New Orleans aquifer (fig. 3). Other aquifers underlying the parish include Mississippi River point bar deposits, the shallow aquifers of the New Orleans area, the Gramercy and Norco aquifers, and the "1,200-foot" sand of the New Orleans area. These other aquifers generally contain very hard ${ }^{2}$ water with high iron concentrations (greater than 300 micrograms per liter $[\mu \mathrm{g} / \mathrm{L}]$ ) or only saltwater (water with chloride concentrations greater than 250 milligrams per liter $[\mathrm{mg} / \mathrm{L}])$. Because of these water-quality concerns, these aquifers generally are not utilized for water supply in Orleans Parish (Prakken, 2009) and are not discussed further in this report. Fresh groundwater also is available from the Evangeline equivalent aquifer system at depths between 2,000 and 2,500 feet (ft) below the National Geodetic Vertical Datum of 1929 (NGVD 29) in a small area in the extreme northeastern part of the parish (Smoot, 1988). Because of the limited extent of the Evangeline equivalent aquifer system within the parish, it is not utilized for water supply in Orleans Parish and is not discussed further in this report.

State well-registration records listed 244 active water wells in Orleans Parish in 2009, including 162 domestic, 46 industrial, 17 public supply, 15 irrigation, and 4 power generation (Louisiana Department of Natural Resources, 2009). In 2010, groundwater withdrawals for various uses included industrial, power generation, rural domestic, and general irrigation (table 2). Almost all groundwater withdrawals in Orleans Parish came from the Gonzales-New Orleans aquifer; water withdrawals from the Gramercy aquifer totaled about $0.02 \mathrm{Mgal} / \mathrm{d}$ (table 1).

\section{Gonzales-New Orleans Aquifer}

The Gonzales-New Orleans aquifer is continuous throughout Orleans Parish and dips in a southerly direction (Tomaszewski, 2003). The aquifer consists of mostly fine to medium sand of uniform texture (Dial and Sumner, 1989). The top of the aquifer is about $230 \mathrm{ft}$ below NGVD 29 in the extreme northeastern corner of the parish (Griffith, 2003) and about 650-700 ft below NGVD 29 in the southern part of the parish (Tomaszewski, 2003). In northeastern Orleans Parish, the Gonzales-New Orleans aquifer is composed of two distinct hydrologic units: a thick basal sand unit bearing saltwater and a thinner upper sand unit bearing freshwater (fig. 3) (Rollo, 1966). Thickness of the basal sands of the aquifer is variable but is generally about $150-200 \mathrm{ft}$ or more in Orleans Parish (Prakken, 2009). Locally, sand lenses and sand streaks thicken the aquifer.

The Gonzales-New Orleans aquifer receives recharge from precipitation and infiltration in areas where it outcrops or subcrops north of Lake Pontchartrain (Dial and Tomaszewski, 1988). The aquifer also receives recharge through overlying and underlying confining units and from adjacent aquifers (Dial and Tomaszewski, 1988). Discharge from the aquifer is primarily by withdrawals from wells.

\footnotetext{
${ }^{2}$ Hardness ranges, expressed as milligrams per liter of calcium carbonate, are as follows: 0-60, soft; 61-120, moderately hard; 121-180, hard; greater than 180 , very hard (Hem, 1985).
} 


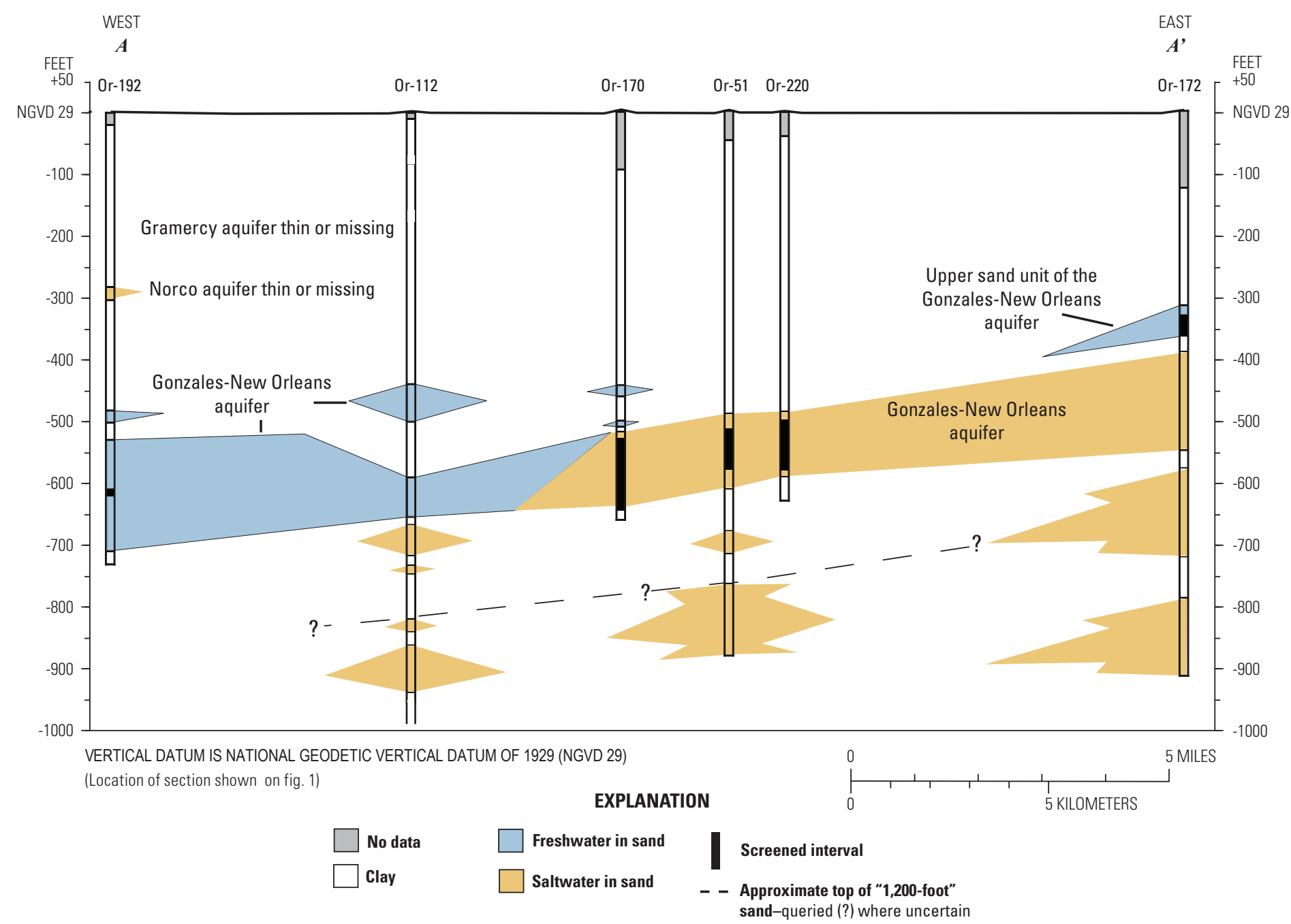

Figure 3. Hydrogeologic section $A-A$ ' showing major sand units from central to northeastern Orleans Parish, Louisiana (modified from Prakken, 2009). Trace of section shown on figure 1.

As discussed previously, fresh groundwater is available from the Gonzales-New Orleans aquifer in Orleans Parish, but saltwater also is present in the aquifer. Within the GonzalesNew Orleans aquifer, the base of freshwater generally ranges from about $350 \mathrm{ft}$ below NGVD 29 in northeastern Orleans Parish to about $750 \mathrm{ft}$ below NGVD 29 in western areas of the parish. In general, the aquifer contains freshwater in areas of the parish north of U.S. Highway 90 and saltwater in areas to the south (fig. 1).

State well-registration records listed 206 active wells screened in the Gonzales-New Orleans aquifer in Orleans Parish in 2009, including 131 domestic, 42 industrial, 16 public supply, 13 irrigation, and 4 power generation. Depths of these wells ranged from 220 to $815 \mathrm{ft}$ below land surface, with a median depth of $490 \mathrm{ft}$. In Orleans Parish, reported well yields have ranged from 1 to 2,600 gallons per minute (Louisiana Department of Natural Resources, 2009).

In 2010, over 98 percent of withdrawals from the GonzalesNew Orleans aquifer in the parish occurred at two locations where the aquifer contains only saltwater. About $10.9 \mathrm{Mgal} / \mathrm{d}$ were withdrawn at a powerplant located about 1.5 miles (mi) southwest of Michoud (fig. 1) near the Gulf Intracoastal
Waterway (GIWW), and about $1.88 \mathrm{Mgal} / \mathrm{d}$ were withdrawn in an industrial area located about $1 \mathrm{mi}$ southeast of Michoud.

In 2008, water levels in the Gonzales-New Orleans aquifer in Orleans Parish ranged from about $21 \mathrm{ft}$ below NGVD 29 in northeastern Orleans Parish to about $145 \mathrm{ft}$ below NGVD 29 near Michoud (Prakken, 2009), and the general direction of water movement in the aquifer was radially toward the withdrawal center southwest of Michoud. Water levels in the Gonzales-New Orleans aquifer generally have risen since the $1970 \mathrm{~s}$ in response to reduced groundwater withdrawals. Total groundwater withdrawals in Orleans Parish, which have been primarily from the Gonzales-New Orleans aquifer, decreased from 43.4 Mgal/d in 1970 (Dial, 1970) to $12.95 \mathrm{Mgal} / \mathrm{d}$ in 2010 (Sargent, 2011) (fig. 2). Water levels at well Or-42, located south of the Mississippi River in Algiers (fig. 1), have risen about $70 \mathrm{ft}$ since 1970 (fig. 4). Water levels in well Or-206, located on the east bank of the Inner Harbor Navigation Canal (fig. 1), rose about $119 \mathrm{ft}$ from 1972 to 2011 (fig. 4). Water levels in the well rose abruptly about $18 \mathrm{ft}$ in 2005 after Hurricane Katrina. Water levels in well Or-175, located in northeastern Orleans Parish (fig. 1) about $8 \mathrm{mi}$ from any pumping center, generally have changed little since 1970 (fig. 4). 


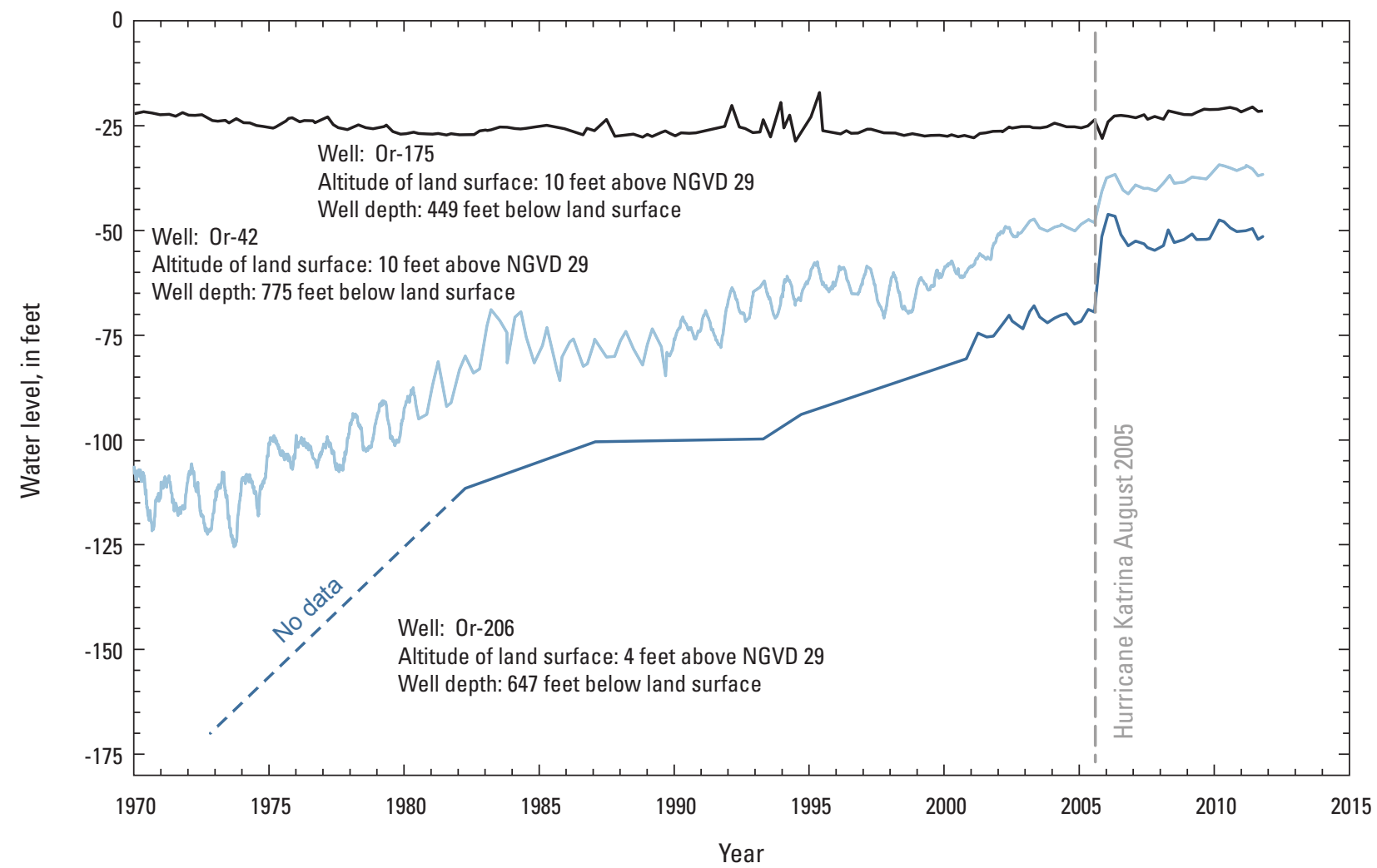

Figure 4. Water levels in wells Or-175, Or-42, and Or-206 screened in the Gonzales-New Orleans aquifer in Orleans Parish, Louisiana (see fig. 1 for well locations; U.S. Geological Survey, 2012a, b, c). Land surface and water level are measured in feet relative to the National Geodetic Vertical Datum of 1929 (NGVD 29).

A statistical summary of selected water-quality characteristics for freshwater samples collected from 84 wells screened in the Gonzales-New Orleans aquifer in Orleans Parish is presented in table 3 . The median value for hardness fell within the soft range. Median values for iron and manganese fell below the U.S. Environmental Protection Agency's Secondary Maximum Contaminant Levels (SMCLs). ${ }^{3}$ Chloride concentrations were below the SMCL and tended to increase toward saltwater areas. Dissolved solids concentrations generally exceed the SMCL of $500 \mathrm{mg} / \mathrm{L}$. Water in the aquifer has a yellow color and exceeds the SMCL of 15 platinum cobalt units.

\section{Surface-Water Resources}

In 2010, about $602 \mathrm{Mgal} / \mathrm{d}$ of surface water were withdrawn in the parish, including about $453 \mathrm{Mgal} / \mathrm{d}$ for power generation, $149 \mathrm{Mgal} / \mathrm{d}$ for public supply, and $0.02 \mathrm{Mgal} / \mathrm{d}$ for livestock (table 2). Although Orleans Parish extends into Lake Pontchartrain, there were no reported water withdrawals from the lake. All public-supply water came from the Mississippi

\footnotetext{
${ }^{3}$ The SMCLs are nonenforceable Federal guidelines regarding cosmetic effects (such as tooth or skin discoloration) or aesthetic effects (such as taste, odor, or color) of drinking water. At high concentrations or values, health implications as well as aesthetic degradation may result. SMCLs were established as guidelines for the States by the U.S. Environmental Protection Agency (1992).
}

River, which is the primary source of fresh surface water in the parish. Water samples analyzed during the period 1967-88 indicated that water in the Mississippi River at New Orleans (site number 07374508) (fig. 1) is generally hard and does not exceed the SMCLs for $\mathrm{pH}$ and concentrations of chloride, sulfate, and iron (table 4). Dissolved oxygen concentrations are generally greater than $5 \mathrm{mg} / \mathrm{L}$, which is considered the minimum value for a diversified population of fresh, warmwater biota, including sport fish (Louisiana Department of Environmental Quality, 2008).

Mississippi River discharge data are not available for Orleans Parish, but the average flow of the Mississippi River near Red River Landing (site number 07373291), about 210 river miles upstream of the parish (fig. 1, index map), was about 460,000 cubic feet per second (about 298,000 Mgal/d) for the period 1928-76 (Wells, 1980). The flow in the Mississippi River near Red River Landing is representative of flows in Orleans Parish because there are no major tributaries or distributaries, and the river is mostly leveed between the landing and the parish.

The GIWW is a deepwater navigation channel that extends through much of Orleans Parish and intersects with the Mississippi River (fig. 1). Locks prevent continuous water exchange between the GIWW and the river. In 2010, about $453 \mathrm{Mgal} / \mathrm{d}$ were withdrawn from the GIWW (table 1) at a power-generation plant near Michoud. Most surface water withdrawn for power generation was used for cooling and returned to the GIWW after use (Sargent, 2011). Water samples analyzed during the period 1974-84 indicated that 
Table 3. Summary of selected water-quality characteristics for freshwater in the Gonzales-New Orleans aquifer in Orleans Parish, Louisiana, 1942-2008 (U.S. Geological Survey, 2011).

[Values are in milligrams per liter, except as noted. ${ }^{\circ} \mathrm{C}$, degrees Celsius; $\mathrm{PCU}$, platinum cobalt units; $\mu \mathrm{S} / \mathrm{cm}$, microsiemens per centimeter; $\mathrm{SU}$, standard units; $\mathrm{CaCO}_{3}$, calcium carbonate; $\mu \mathrm{g} / \mathrm{L}$, micrograms per liter; SMCL, Secondary Maximum Contaminant Level established by the U.S. Environmental Protection Agency, 2011; NA, not applicable]

\begin{tabular}{|c|c|c|c|c|c|c|c|c|c|}
\hline & $\begin{array}{l}\text { Temper- } \\
\text { ature }\left({ }^{\circ} \mathrm{C}\right)\end{array}$ & $\begin{array}{l}\text { Color, } \\
\text { (PCU) }\end{array}$ & $\begin{array}{c}\text { Specific } \\
\text { conductance, } \\
\text { field }(\mu \mathrm{S} / \mathrm{cm} \text { at } \\
\left.25^{\circ} \mathrm{C}\right)\end{array}$ & $\begin{array}{l}\text { pH, } \\
\text { field } \\
\text { (SU) }\end{array}$ & $\begin{array}{l}\text { Hardness } \\
\text { (as } \mathrm{CaCO}_{3} \text { ) }\end{array}$ & $\begin{array}{c}\text { Chloride, } \\
\text { filtered } \\
\text { (as CI) }\end{array}$ & $\begin{array}{c}\text { Iron, } \\
\text { filtered } \\
\text { ( } \mu \mathrm{g} / \mathrm{L} \text { as } \\
\mathrm{Fe})\end{array}$ & $\begin{array}{c}\text { Manganese, } \\
\text { filtered } \\
(\mu \mathrm{g} / \mathrm{L} \text { as } \mathrm{Mn})\end{array}$ & $\begin{array}{l}\text { Dissolved } \\
\text { solids, } \\
\text { filtered }\end{array}$ \\
\hline Median & 25.0 & 160 & 972.5 & 8.1 & 19.5 & 82.5 & 140 & 25 & 594 \\
\hline 10th percentile & 23.0 & 92 & 721.6 & 7.2 & 10 & 37.6 & 45 & 13 & 438.5 \\
\hline Number of samples & 27 & 33 & 40 & 39 & 76 & 84 & 6 & 4 & 22 \\
\hline $\begin{array}{l}\text { Percentage of samples } \\
\text { that do not exceed } \\
\text { SMCLs }\end{array}$ & NA & 0 & NA & 100 & NA & 100 & 67 & 75 & 36 \\
\hline \multicolumn{10}{|c|}{ SMCLs } \\
\hline
\end{tabular}

Table 4. Summary of selected water-quality characteristics for the Mississippi River and the Gulf Intracoastal Waterway in Orleans Parish, Louisiana (U.S. Geological Survey, 2011).

[Values are in milligrams per liter, except as noted. $\mu \mathrm{S} / \mathrm{cm}$, microsiemens per centimeter; ${ }^{\circ} \mathrm{C}$, degrees Celsius; $\mathrm{SU}$, standard units; $\mathrm{CaCO}_{3}$, calcium carbonate; $\mu \mathrm{g} / \mathrm{L}$, micrograms per liter; <, less than; SMCL, Secondary Maximum Contaminant Level established by the U.S. Environmental Protection Agency, 2011; NA, not applicable]

\begin{tabular}{|c|c|c|c|c|c|c|c|c|c|c|}
\hline & $\begin{array}{c}\text { Specific } \\
\text { conduc- } \\
\text { tance, field } \\
(\mu \mathrm{S} / \mathrm{cm} \text { at } \\
\left.25^{\circ} \mathrm{C}\right)\end{array}$ & $\begin{array}{l}\text { Oxygen, } \\
\text { dissolved }\end{array}$ & $\begin{array}{l}\text { pH, } \\
\text { field } \\
\text { (SU) }\end{array}$ & $\begin{array}{l}\text { Hardness } \\
\text { (as } \mathrm{CaCO}_{3} \text { ) }\end{array}$ & $\begin{array}{l}\text { Calcium, } \\
\text { filtered } \\
\text { (as Ca) }\end{array}$ & $\begin{array}{c}\text { Magnesium, } \\
\text { filtered } \\
\text { (as } \mathbf{M g} \text { ) }\end{array}$ & $\begin{array}{l}\text { Sodium, } \\
\text { filtered } \\
\text { (as Na) }\end{array}$ & $\begin{array}{l}\text { Chloride, } \\
\text { filtered } \\
\text { (as CI) }\end{array}$ & $\begin{array}{l}\text { Sulfate, } \\
\text { filtered } \\
\text { (as } \mathrm{SO}_{4} \text { ) }\end{array}$ & $\begin{array}{c}\text { Iron, } \\
\text { filtered } \\
\text { ( } \mu \mathrm{g} / \mathrm{L} \\
\text { as Fe) }\end{array}$ \\
\hline \multicolumn{11}{|c|}{ Mississippi River at New Orleans, $1967-88^{1}$} \\
\hline Median & 406 & 8.0 & 7.6 & 150 & 41 & 12 & 22 & 24 & 53 & 20 \\
\hline 90th percentile & 498 & 11.0 & 8.0 & 180 & 48 & 15 & 33 & 34 & 74 & 50 \\
\hline Number of samples & 198 & 158 & 186 & 181 & 181 & 181 & 180 & 183 & 182 & 43 \\
\hline $\begin{array}{l}\text { Percentage of } \\
\text { samples that } \\
\text { do not exceed } \\
\text { SMCLs }\end{array}$ & NA & NA & 100 & NA & NA & NA & NA & 100 & 100 & 100 \\
\hline 10th percentile & 3,690 & 6.3 & 7.4 & 390 & 38 & 67 & 1,400 & 1,600 & 140 & $<10$ \\
\hline 90th percentile & 20,700 & 10.2 & 7.9 & 2,400 & 150 & 480 & 3,800 & 7,000 & 980 & 70 \\
\hline Number of samples & 126 & 120 & 126 & 120 & 111 & 112 & 48 & 125 & 123 & 125 \\
\hline $\begin{array}{l}\text { Percentage of } \\
\text { samples that } \\
\text { do not exceed } \\
\text { SMCLs }\end{array}$ & NA & NA & 100 & NA & NA & NA & NA & 0 & 16 & 99 \\
\hline \multicolumn{11}{|c|}{ SMCLs } \\
\hline & NA & NA & $6.5-8.5$ & NA & NA & NA & NA & 250 & 250 & 300 \\
\hline
\end{tabular}

${ }^{1}$ Site number 07374508 (U.S. Geological Survey, 2010; specific data at http://nwis.waterdata.usgs.gov/usa/nwis/qwdata/?site_no=07374508).

${ }^{2}$ Site number 300024089560500 (U.S. Geological Survey, 2009; specific data at http://nwis.waterdata.usgs.gov/usa/nwis/qwdata/?site_no=300024089560500). 
water in the GIWW, east of the Mississippi River, at the former New Orleans Public Service Incorporated Plant ${ }^{4}$ (site number 300024089560500) (fig. 1) is generally very hard and does not exceed the SMCL for pH (table 4). The water is salty with chloride concentrations well above the $250 \mathrm{mg} / \mathrm{L}$ SMCL. The median value for sulfate concentrations exceeds the SMCL of $250 \mathrm{mg} / \mathrm{L}$. Dissolved oxygen concentrations are generally greater than $5 \mathrm{mg} / \mathrm{L}$.

${ }^{4}$ New Orleans Public Service Incorporated Plant is now known as Entergy Michoud Plant.

\section{References Cited}

Dial, D.C., 1970, Pumpage of water in Louisiana, 1970: Department of Conservation, Louisiana Geological Survey, and Louisiana Department of Public Works Water Resources Pamphlet no. 26, 10 p.

Dial, D.C., and Sumner, D.M., 1989, Geohydrology and simulated effects of pumpage on the New Orleans aquifer system at New Orleans, Louisiana: Louisiana Department of Transportation and Development Water Resources Technical Report no. 46, 54 p.

Dial, D.C., and Tomaszewski, D.J., 1988, Geohydrology, water quality, and effects of pumpage on the New Orleans aquifer system, northern Jefferson Parish, Louisiana: U.S. Geological Survey Water-Resources Investigations Report 88-4097, 34 p., accessed August 6, 2012, at http:// pubs.usgs.gov/wri/1988/4097/report.pdf.

Griffith, J.M., 2003, Hydrogeologic framework of southeastern Louisiana: Louisiana Department of Transportation and Development Water Resources Technical Report no. 72, 21 p., 18 pls.

Hem, J.D., 1985, Study and interpretation of the chemical characteristics of natural water ( $3 \mathrm{~d}$ ed.): U.S. Geological Survey Water-Supply Paper 2254, 264 p., accessed February 20, 2013, at http://pubs.er.usgs.gov/ publication/wsp2254.

Louisiana Department of Environmental Quality, 2008, Environmental Regulatory Code, Title 33, Part IX, Subpart 1: Baton Rouge, Louisiana Department of Environmental Quality, accessed June 9, 2009, at http:www.deq.louisiana.gov/portal/tabid/1674/Default.aspx.

Louisiana Department of Natural Resources, 2009, Strategic Online Natural Resources Information System (SONRIS): Louisiana Department of Natural Resources database, accessed March 12, 2010, at http://sonris. $\mathrm{com} /$.

Prakken, L.B., 2009, Groundwater resources in the New Orleans area, 2008: Louisiana Department of Transportation and Development Water Resources Technical Report no. 80,36 p.

Rollo, J.R., 1966, Ground-water resources of the greater New Orleans area, Louisiana: Department of Conservation, Louisiana Geological Survey, and Louisiana Department of Public Works Water Resources Bulletin no. $9,69 \mathrm{p}$.

Sargent, B.P., 2011, Water use in Louisiana, 2010: Louisiana Department of Transportation and Development Water Resources Special Report no. $17,135 \mathrm{p}$.

Smoot, C.W., 1988, Louisiana hydrologic atlas map no. 3-Altitude of the base of freshwater in Louisiana: U.S. Geological Survey WaterResources Investigations Report 86-4314, 1 sheet, accessed November 2, 2011, at http://pubs.er.usgs.gov/publication/wri864314.
Tomaszewski, D.J., 2003, Ground-water resources along the lower Mississippi River, southeastern Louisiana: Louisiana Department of Transportation and Development Water Resources Technical Report no. $69,23 \mathrm{p}$.

U.S. Environmental Protection Agency, 1992, Secondary Drinking Water Regulations - Guidance for nuisance chemicals: U.S. Environmental Protection Agency publication EPA 810/K-92-001, 4 p., accessed September 28, 2011, at http:/water.epa.gov/drink/contaminants/ secondarystandards.cfm.

U.S. Environmental Protection Agency, 2011, 2011 Edition of the drinking water standards and health advisories: U.S. Environmental Protection Agency publication EPA 820-R-11-002, Office of Water, 12 p., accessed September 2, 2011, at http://water.epa.gov/action/advisories/drinking/ upload/dwstandards2011.pdf.

U.S. Geological Survey, 2011, Water quality samples for Louisiana: National Water Information System Web Interface, accessed November 18, 2011, at http://nwis.waterdata.usgs.gov/la/nwis/qwdata/.

U.S. Geological Survey, 2012a, Groundwater levels for Louisiana [data for USGS 300525089464001 Or-175]: accessed March 21, 2012, at http:/ nwis.waterdata.usgs.gov/la/nwis/gwlevel/?site_no $=300525089464001$.

U.S. Geological Survey, 2012b, Groundwater levels for Louisiana [data for USGS 295652090020101 Or-42]: accessed March 21, 2012, at http:// nwis.waterdata.usgs.gov/la/nwis/gwlevel/?site_no=295652090020101.

U.S. Geological Survey, 2012c, Groundwater levels for Louisiana [data for USGS 300027090013201 Or-206]: accessed March 21, 2012, at http:// nwis.waterdata.usgs.gov/la/nwis/gwlevel/?site_no=300027090013201.

Wells, F.C., 1980, Hydrology and water quality of the lower Mississippi River: Louisiana Department of Transportation and Development, Office of Public Works Water Resources Technical Report no. 21, 83 p.

This fact sheet was published by the U.S. Geological Survey, in cooperation with the Louisiana Department of Transportation and Development (DOTD). Thanks are given to Zahir "Bo" Bolourchi, Director, Water Resources Programs, DOTD, who contributed to the content of the fact sheet.

\section{By Lawrence B. Prakken, Vincent E. White, and John K. Lovelace}

\section{For additional information, contact:}

Director, USGS Louisiana Water Science Center

3535 S. Sherwood Forest Blvd., Suite 120

Baton Rouge, LA 70816

E-mail: dc_la@usgs.gov

Fax: (225) 298-5490

Telephone: (225) 298-5481

Home Page: http://la.water.usgs.gov 